\title{
The Study of Fatigue Failure Performance of Vehicle Metal Structures Used in Transportation of Corrosive Materials
}

\author{
Pavlo Popovych ${ }^{1}$, Liubov Poberezhna ${ }^{2}$, Oleg Lyashuk ${ }^{1}$, Oleg Tson ${ }^{1}, 0$ oksana Shevchuk ${ }^{1}$, Janette \\ Brezinová ${ }^{3}$ and Anna Guzanová $3, *$
}

\author{
Ternopil Ivan Puluj National Technical University, Ruska str. 56, Ternopil, Ukraine \\ ${ }^{2}$ Ivano Frankivsk National Medical University, Galytska str. 2, Ivano-Frankivsk, Ukraine
}

${ }^{3}$ Technical University of Košice, Letná 9, Košice, Slovakia

\begin{abstract}
The processes of corrosion-fatigue failure of materials in contact with mineral fertilizers are insufficiently studied. As a result of joint influence of atmospheric corrosion and mechanical loads, about 70 to $80 \%$ of machine parts get out of order, 20 to $25 \%$ of which are failures caused by operating overload due to the strength loss because of atmospheric corrosion. A large part of metal structures of agricultural vehicles used to transport mineral fertilizers is under the direct influence of aggressive environments and dynamic loads that occur during the motion by field roads. Saturated solutions of the most aggressive working environments used in agricultural production, in particular ammonium sulphate and nitrophosphate are investigated to reduce fatigue resistance of ordinary steels groups - St3 and St5 (GOST 2651:2005; DIN 17100) and quality steels - 10 Steel, 15 Steel, 20 Steel, 25 Steel (GOST 1050-88; DIN 17200) when loaded at all levels. The fatigue endurance limit decreases in comparison with air up to 2.02 times in a solution of ammonium sulphate, and to 2.32 times in a solution of nitrophosphate. In organic fertilizer environments, compared to distilled water, the conditional fatigue endurance limit increased to $9 \%$. The properties of the given materials as an inhibitor of corrosion-fatigue failure were discovered and proved.
\end{abstract}

Keywords: Tractor-trailer, metal structure, carbon steels, agricultural working environment, fatigue fracture, fatigue limit.

\section{Introduction}

The key factors of fatigue and corrosion-fatigue failure of vehicle metal structures used in agricultural production determine the state of working surfaces, load parameters, environments aggressiveness degrees in consideration of the different kinds of fertilizer, weather conditions, etc. $[3,7,8]$. On examining the technical state of agricultural machinery after 3 years of operation, it is observed that corrosion contributes to approximately $80 \%$ of all mechanical failures of assembly units $[8,9]$, Fig. 1, Fig. 2. The corrosion fatigue failure is the result of additive effects of service loads, environments, and thermodynamic lability of metal structures materials. Corrosion damages and light-gage sheet metal failures change a state of workpiece surface and intensify the wear processes. They significantly degrade tribotechnical 
properties and corrosion processes, causing a simultaneous decrease in fatigue strength. As a result, the reliability and durability of vehicles are significantly reduced.

The processes of corrosion-fatigue failure of materials in contact with organic and mineral fertilizers are insufficiently studied. The absence of reliable data makes it difficult to develop new effective methods of corrosion protection of agricultural fertilizing machines. In particular, in $[2,3,5]$, two steels are studies without taking into account the fact that for manufacturing metal structures of this class machinery, the whole range of standard and quality steels are applied. There is a need for experimental research of the whole range of metal materials of tractor-trailers, fertilizing machines, etc. under the influence of corrosive agricultural environments. The results of such research could be used as input data for the objective and quantitative assessment of operability parameters of the given type vehicles.
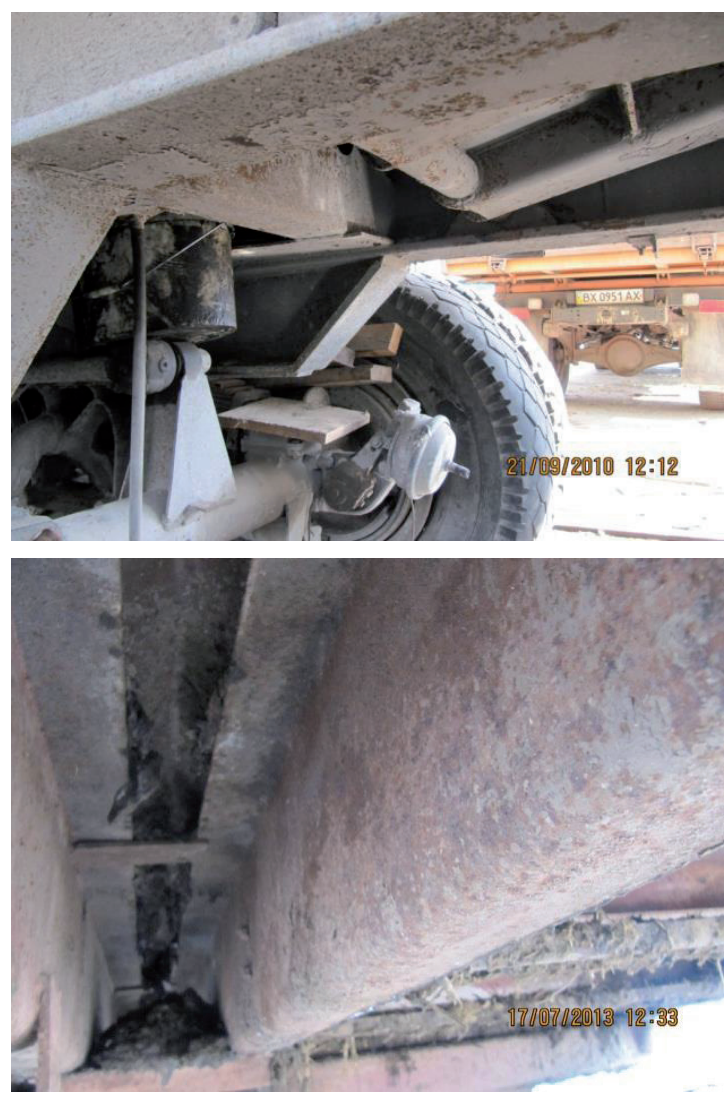

Fig. 1: Corrosion-fatigue failures of machine units used in agricultural production.
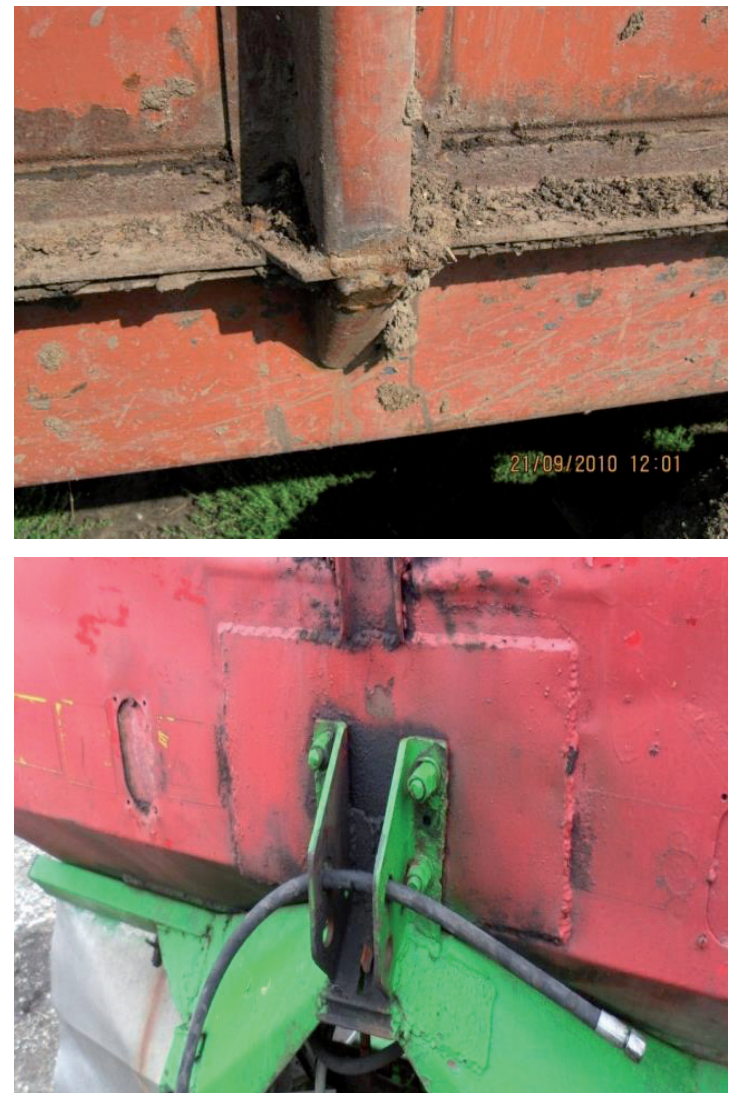

Fig. 2: Welded fatigue failures of light-gage sheet metal structures of trailers.

\section{Materials and technique}

For fatigue and corrosion fatigue tests [1], the cylindrical specimens (Fig. 3) with a diameter of 10 mm (GOST 23026-78) made of standard steels St3, St5 (ISO 2651: 2005; DIN 17100) and quality steels 10 Steel, 15 Steel, 20 Steel, 25 Steel (GOST 105088; DIN 17200) under supply condition were used. The working body was an aluminum oxide wheel ЭB25SMIK. After turning, the grinding allowance was $0.35 \mathrm{~mm}$. Rotation velocity of a specimen was 3 $\mathrm{m} / \mathrm{min}$, linear velocity of a stone $-30 \mathrm{~m} / \mathrm{sec}$, depth of grinding during the final passage $-0.005 \mathrm{~mm} / \mathrm{rev}$, surface roughness $\mathrm{Rz}=2.5 \mu \mathrm{m}$.

To eliminate the traces of mechanical grinding and to provide the fine precision of obtained results, the working area of all specimens before testing was polished using a sandpaper and diamond pastes with different dispersion. The same type of manufacturing technology was applied for manufacturing the batch of specimens. Therefore, the specimen designation was carried out on 
both specimen holders (Fig. 3). The precision of measurements of the prepared specimens working area was $0.01 \mathrm{~mm}$.

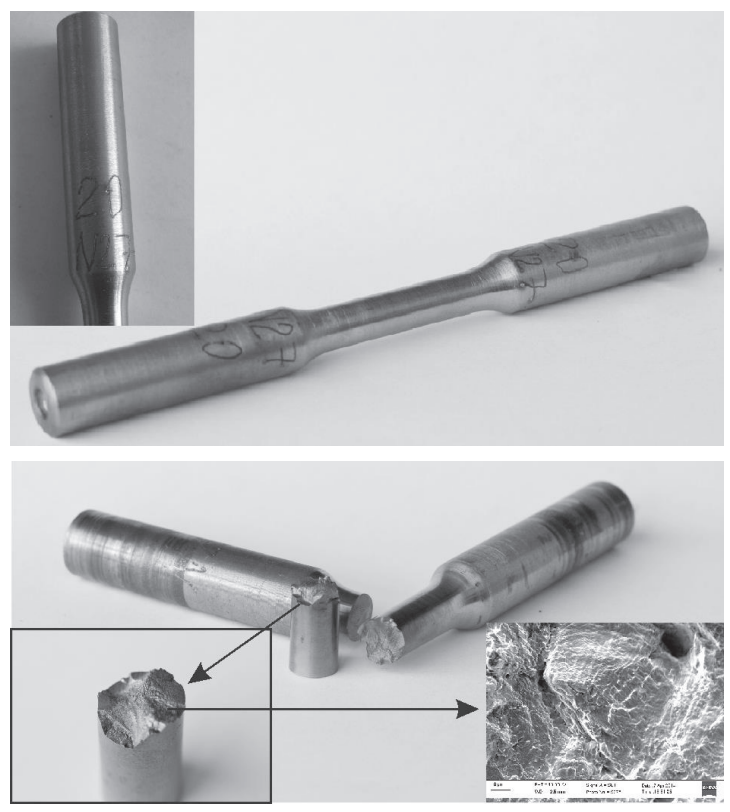

Fig. 3: General appearance and specimen designation for fatigue tests before and after study.

Distilled water as a standard test condensate of water or rainwater, saturated solutions of ammonium sulphate and nitrophosphate, mixed liquid manure of cattle and pigs in proportion $1 / 2$ acted as corrosive environments $[2,3,5,10]$. Acidity levels of environments before and after the experimental studies were measured by $\mathrm{pH}$ meter I-160M. Fatigue tests were carried out on the equipment IMA-5. The specimens were loaded by the scheme of rotating bend; cycle asymmetry coefficient was $R=-1[1,2,5,6]$. A fast-speed counting device before fracture $\mathrm{N}$ fixed the number of cycles. Based on obtained data, the Wohler curves were built. Tests started at $2 / 3 \sigma_{\theta}$, incrementally reducing the value to the limit of endurance $\sigma_{-1}$ within the framework of research $\left(10^{7}\right.$ cycles - when tested in air, $5 \cdot 10^{7}$ cycles - in environments under study). As a research material, 5-15 specimens at a level of stress $\left(0.95 \ldots\right.$... 1.05) $\sigma_{-1}$ were used. Based on the research results, the fatigue limit was determined. Two specimens under study remained non-failed after reaching the specified database of testing. After examining 10-15 specimens, the fatigue curves were built [1].

\section{Results and Discussion}

The study of ordinary steels St3, St5 (GOST 2651:2005; DIN 17100) and quality steels - 10 Steel, 15 Steel, 20 Steel, 25 Steel (GOST 1050-88; DIN 17200) proved that in the whole range of loads, the resistance of quality steels to corrosion-fatigue failure in environments of mineral fertilizers, as compared with air and standard test environment condensate (rainwater), was significantly reduced. (Fig. 1, Tab. 1).

In a solution of ammonium sulphate, the conventional limit of quality steels corrosion fatigue, maximum for 10 Steel, decreased to 2.02 times, in a solution of nitrophosphate - to 2.31 times compared with air, accordingly, to 1.3 and 1.49 times compared with distilled water. In organic fertilizer environments, compared to distilled water, the conditional fatigue endurance limit increased to 9\%. Therefore, the properties of the given material as an inhibitor of corrosion-fatigue failure were discovered and proved $[2,3]$. The same tendencies in resistance to corrosion-fatigue failure in environments under study are observed in ordinary steels St3, St5 (Fig. 4, Tab. 1).

Less intense impact on the steels fatigue endurance limit of two groups of mixed manure under study compared to mineral fertilizers was noticed. However, the negative impact of
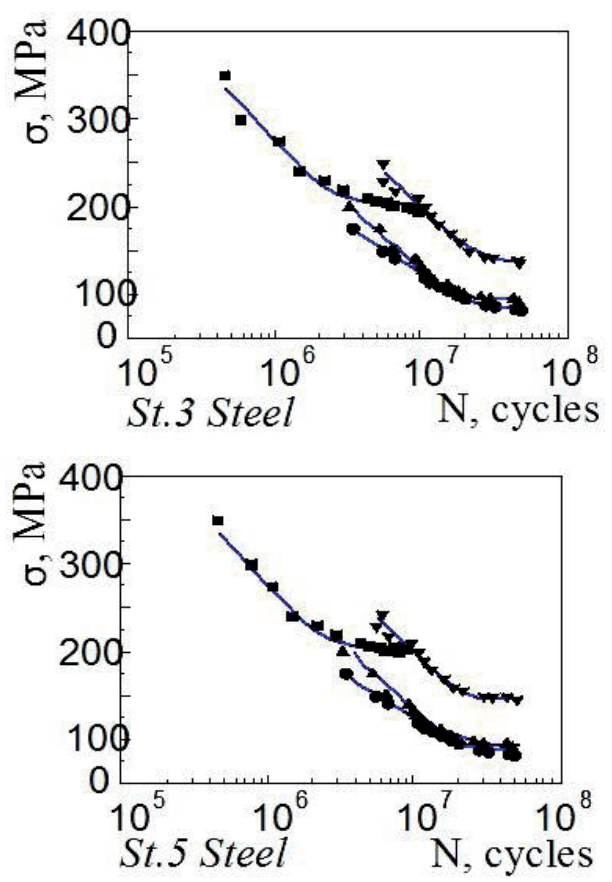

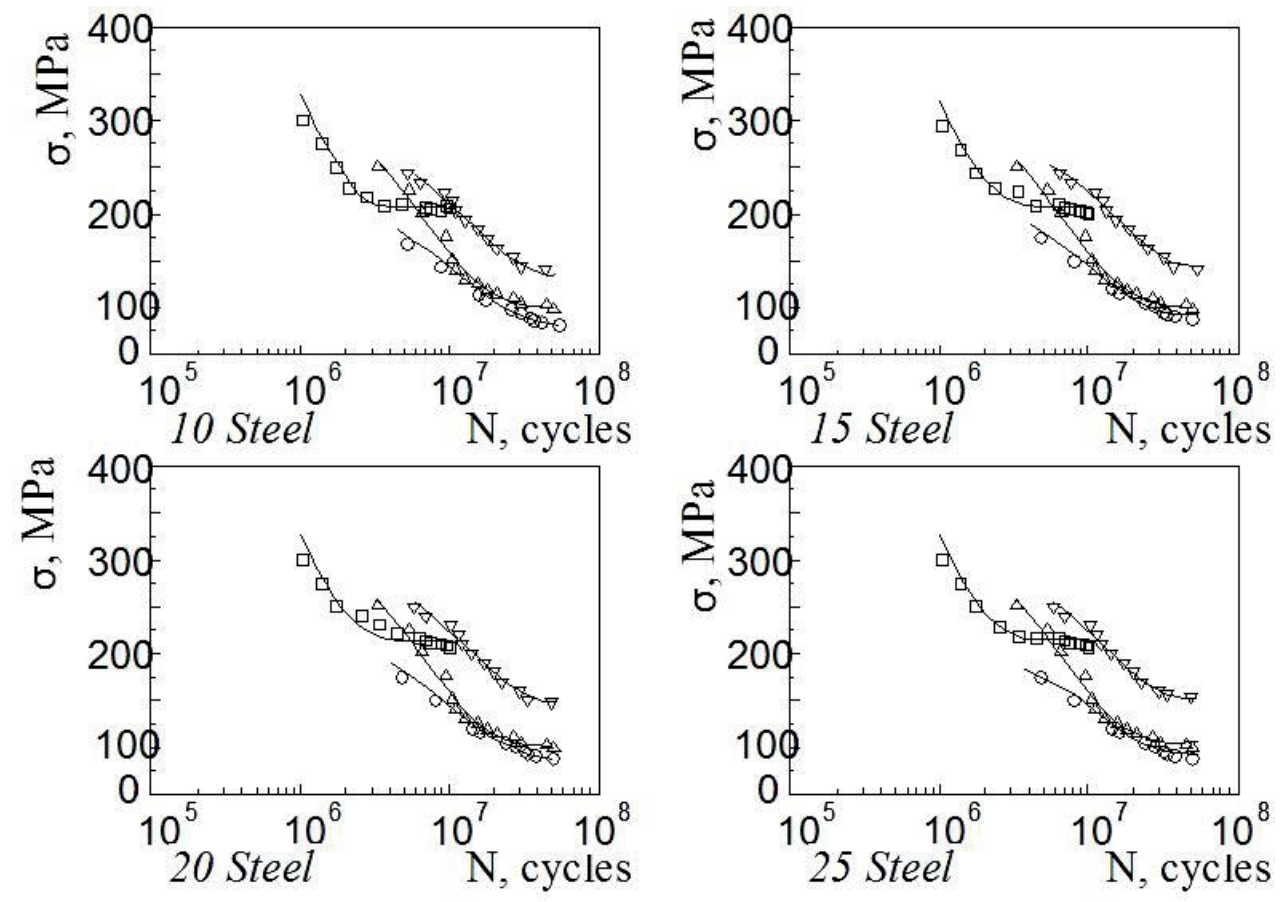

Fig. 4: Fatigue curves of standard steels and quality steels in working environments: air -

$\mathbf{O}, \mathbf{O}$; saturated solution of ammonium sulphate $\triangle, \boldsymbol{\Delta}$; fixed manure - $\nabla$

Table 1: Fatigue endurance limits of metal structure materials in working environments, MPa.

\begin{tabular}{|l|l|l|l|l|l|}
\hline \multirow{2}{*}{ Steel } & \multirow{2}{*}{ Air } & \multirow{2}{*}{ Organic fertilizer } & \multirow{2}{*}{ Distilled water } & \multicolumn{2}{c|}{ Mineral fertilizers } \\
\cline { 5 - 6 } & & & & Ammonium sulphate & Nitrophosphate \\
\hline St3 & 197 & 139 & 121 & 93 & 85 \\
\hline St5 & 208 & 146 & 127 & 98 & 89 \\
\hline 10 Steel & 192 & 135 & 124 & 95 & 83 \\
\hline 15 Steel & 202 & 143 & 136 & 102 & 90 \\
\hline 20 Steel & 207 & 147 & 135 & 104 & 90 \\
\hline 25 Steel & 219 & 156 & 143 & 111 & 96 \\
\hline
\end{tabular}

environment on the conditional fatigue endurance limit in comparison with the standard test rainwater was not noticed.

\section{Conclusions}

The influence of the most aggressive environments of agricultural production on fatigue fracture of agricultural trailers steel elements is analyzed. In particular, in the whole range of applied loads, the resistance of ordinary steels groups under study - St3, St5 (ISO 2651: 2005; DIN 17100) and quality steels under study - 10 Steel, 15 Steel, 20 Steel, 25 Steel (GOST 1050-88; DIN 17200) to the corrosion- fatigue failure in mineral fertilizers environments compared with air decreased significantly. In a solution of ammonium sulphate, the conditional fatigue endurance limit of steel quality decreased to 2.02 times, in a solution of nitrophosphate - to 2.31 times as compared with air, and to 1.3 and 1.49 times compared to distilled water. In organic fertilizer environment, the conditional fatigue endurance limit increased to $9 \%$ compared to standard test rainwater. The resistance to the corrosion-fatigue failure of ordinary steels occurred to be lower than quality steels. Less intense impact of organic fertilizers on the fatigue endurance limit of both 
steels compared to mineral fertilizers was noticed.

\section{References}

[1] Pokhmurskyi, V. I., Khoma M. S. (2008). Corrosion Fatigue of Metals and Alloys. (Корозійна втома металів та сплавів). Spolom, Lviv.

[2] Popovych P. (2014). Peculiarities of Corrosion and Corrosion Fatigue Behavior of 20 Steel in Water Environments of Mineral and Organic Fertilizers. Corrosion and Corrosion Resistance of Materials (Corrosion-2014), Physical and Chemical Mechanics of Materials, Vol. 2, special edition, No. 12, 833838.

[3] Popovich, P. V., Slobodyan, Z. B. (2014). Corrosion and Electrochemical Behaviors of 20 Steel and St.3 Steel in Ammonium Sulfate and Nitrophoska. Materials Science, Vol. 49, No. 6, 819-826.

[4] Severnev, M. M., Kaplun, G. P., Korotkevych, V. A., Kot, S. N. (1972). The Wear of Agricultural Machinery. Kolos Publishers, Leningrad.

[5] Barna, R. A., Popovich, P. V. (2014). Influence of Operating Media on the Fatigue Fracture of Steels for Elements of Agricultural Machines. Materials Science, Vol. 50, No. 3, 377-380.

[6] Shchurin, K. V. (1994). Prediction and the Increase of Fatigue Durability of Agricultural Tractor Trailers Bulk Systems. OPI, Orenburg.

[7] Severnyi, A. E. (1993). The Corrosion Resistance of Agricultural Machinery (Сохраняемость и защита от коррозии сельскохозяйственной техники). GOSNITI, Moscow.

[8] Gaydar, S. M. (2011). The Wear and Corrosion Resistance of Agricultural Machinery by Means of Nanotechnologies. MSAU, Moscow.

[9] Severnev, M. M., Podlecarev, N. N., Sokhagze, V. Sh. et al. (2011). Wear and Corrosion of Agricultural Machinery. Navuka, Minsk.

\section{Biographical notes}

Pavlo Popovych, DrSc. prof., Ing, PhD.: he graduated from the Ternopil Ivan Puluj National Technical University, Mechanical Faculty, in 1995. Position: Professor, Head of the Department of transport technology. Specialization: mechanics, transport technologies, methods for assessing and improving life supporting systems of vehicles with regard aggressively - operational factors. He was written more than 200 publications (in English, Russian and Ukrainian languages) in the area of transport technologies, fracture mechanics, resource of constructions of vehicles, technical diagnostics.

Liubov Poberezhna, PhD.: she graduated from the Precarpathian National University, Mathematic Faculty in 2002. Position: Associate Professor of the Department of Medical Informatics, Medical and Biological Physics. Specialization: Ecological problems of war affected territory, Environmental safety. She publishes in the area earth sciences, ecological risk analysis and management, soil mechanics etc.
Oleg Lashuk, DrSc. prof., Ing, PhD.: he graduated from the Ternopil Ivan Puluj National Technical University, Faculty of Computer Technologies, in 2001. Position: Professor, Head of the Department of automobile transport. Specialization: mechanics, automobile transport, transport and technological machines mechanisms, the impact of kinematic parameters of bounce and pitch motions of wheeled vehicles with nonlinear characteristics. He was written more than 200 publications (in English, Russian and Ukrainian languages) in the area of technical diagnostics, transport - technological machines mechanisms.

Oleg Tson, PhD., Assistant Professor: graduated from the Ternopil Ivan Puluj National Technical University (Ukraine), Faculty of Food Engineering in 2011. Speciality: Agricultural Production Machines and Mechanization Means. Position: Vice-dean, Assistant Professor of Transport Technology Department at Ternopil Ivan Puluj National Technical University, Faculty of Engineering of Machines, Structures and Technologies. Specialization: diagnostic materials and structures, mechanical engineering, transportation. He was written more than 32 publications (in English, Russian and Ukrainian languages) in the area of mechanical engineering, transportation. Member of the editorial board of the international Journal of Sustainable Development of Transport and Logistics.

Oksana Shevchuk, PhD.: she graduated from the Ternopil Ivan Puluj National Technical University, Mechanical Faculty, in 2007. Position: Associate professor of the Department of transport technology in Ternopil Ivan Puluj National Technical University. Specialization: Mechanics, transport technologies. He was written more than 40 publications (in English, Russian and Ukrainian languages) in the area of transport technologies, mechanical engineering, fracture mechanics.

Janette Brezinová, prof. Ing. PhD.: she graduated from the Technical University of Košice in 1991, PhD. degree received in Mechanical Technology and Materials from the Technical University of Košice in 2003. She is full professor of Production Technology at the Department of Mechanical Technology and Materials of the Faculty of Mechanical Engineering, Technical University of Košice. Her research interests include optimization of finalizing treatment of engineering products, quality of surfaces and coatings, application of modern methods of corrosion monitoring, assessment of the properties of materials and coatings in tribological conditions, wear of materials and coatings, restoration technology.

Anna Guzanová, Assoc. prof. Ing. PhD.: she graduated from the Technical University of Košice in 1997, PhD. degree received in Mechanical Technology and Materials from the Technical University of Košice in 2003. She is an associated professor of the Department of Mechanical Technology and Materials of the Faculty of Mechanical Engineering, Technical University of Košice. Her research interests include quality of surfaces and surface layers, mechanical and chemical pretreatment of technical surfaces, protective and functional coatings based on organic and inorganic materials. 